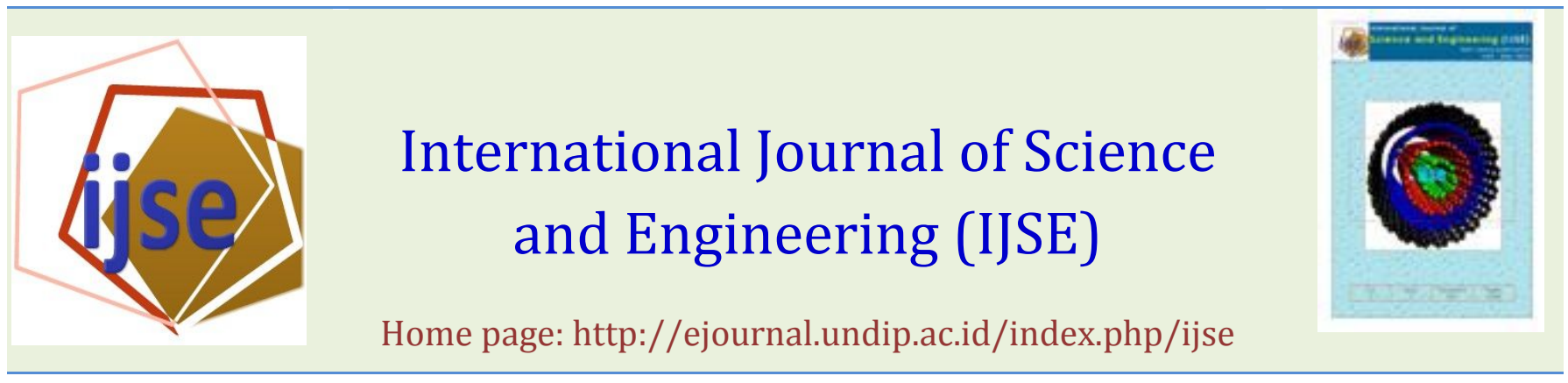

\title{
Analysis of Erosion Level Using Map Windows Agricultural Non-point Source Pollution (MWAGNPS) on Jeneberang Sub-watershed South Sulawesi Province
}

\author{
Ahmad Rifqi Asribin', M. Yanuar J. Purwanto², Sukandi S. ${ }^{2}$, Erizal ${ }^{2}$ \\ Email: ahmad_rifqiasrib@yahoo.co.id \\ 1 Civil Engineering Department Faculty of Engineering, Makassar State University \\ Gunungsari Campus Jl. A.P. Pettarani Makassar 90124 \\ 2 Department of Civil and Environmental Engineering \\ Faculty of Agricultural Engineering, Bogor Agricultural University \\ IPB Campus Dramaga Bogor
}

\begin{abstract}
The aims of this study was to obtain information about the level of soil erosion in Jeneberang sub watershed, as well as the impact of land management and information to determine the direction of land management in the watershed. The approach model used is MWAGNPS. MWAGNPS Model is a model of cell-based rainfall events with the main components are topographic maps, land use and soil type. This model is able to determine the source of erosion and the erosion that occurs. Simulation model showed when Jeneberang watershed has $31.66 \mathrm{~mm}$ of rain events with 30-minute rainfall intensity (EI30) can caused erosion 44.81 tons / ha and the sedimentation rate is 2,22 tons / ha. The source of erosion in Jeneberang sub watershed from farm/moor caused erosion is 29552.14 tons / ha and a total of 4,562,625.84 tons of sediment.
\end{abstract}

Key words - land erosion level; MWAGNPS model; land management

Submission: September 2, $2013 \quad$ Corrected : October 1, 2013

Accepted: October 15, 2013

Doi: $10.12777 /$ ijse.6.1.56-60

[How to cite this article: Asrib, A.R., Purwanto, M.Y.J. , Sukandi, S., Erizal. (2013). Analysis of The Erosion Level Using Map Windows Agricultural Nonpoint Source Pollution (MWAGNPS) on Jeneberang Sub-watershed South Sulawesi Province. International Journal of Science and Engineering, 6(1):11-15. Doi: 10.12777/ijse.6.1.56-60

\section{INTRODUCTION}

Land erosion is a natural event happens on the land surface. The level of erosion depends on various natural factors in the location; however, human now has important role as the cause of the erosion. The natural factors causing erosion include land erodibility, landscape characteristic and rainfall. Due to human activities causing the increase in erosion level, such as inappropriate land use and/or land management that does not based on soil and water conservation, an analysis is needed on the land erosion level in order to be able to conduct land management to maximize land productivity without underestimating the sustainability of natural resources.

Several researchers have made estimates of erosion and sub-watershed sediment with various simulation models. Abdulah et al. (2003) used GIS simulation model of land use. Boix-Fayos et al (2008) have examined the impact of land use change and check-dams on catchment sediment results with the application of erosion models WATEM-SEDEM.

MWAGNPS (Map Windows Agricultural Non-Point Source Pollution) model is a model, using Map Window as an interface, that able to simulate surface run-off, sediment and nutrient transport especially from agricultural watershed. The model has the ability to produce erosion characteristic happening in every point in all watershed networks. This ability is based on cell-model used. Uniform square cells divide the river watershed, and all characteristics of river watershed with input stated in cell level. Component of model uses an equation and methodology admitted and used by conservation research agency such as Land Conservation USDA. Run-off volume 
and peak discharge are estimated using SCS run-off curve number method. Land erosion and sediment rate is estimated using modification form of Universal Soil Loss Equation (USLE) erosion equation (Arsyad, S. 2006). Sediment is channeled from cell to cell through watershed to an outlet using sediment transport based on continuity equation.

MWAGNPS application needs DEM (Digital Elevation Model) data to produce a specific image of LS factor in every cell. In its development, there are some formulas to determine DEM-based LS factor value in MWAGNPS considering slope heterogeneity and prioritizing flow direction and accumulation in its calculation (Luis F. Leon and Chris George, 2009). All watershed characteristics and other inputs are informed in every cell. A single cell can be made with resolution of 2.5 hectare to 40 acre $(1$ acre $=$ $\left.4.047 \mathrm{~m}^{2}\right)$. The size of a small cell such as 10 ha $(200 \times 200$ cell) is suggested for watershed less than 2.000 ha (8 $\mathrm{km}^{2}$ ). For an area more than 2.000 ha, cell with size of 40 ha $(400 \times 400 \mathrm{~m})$ is used for discritisize a watershed.

The research aims to apply MWAGNPS to predict erosion using modified USLE method. It is hoped that the research result gives more specific spatial display on soil erosion level from the existence cells value that can be used in the determination of an appropriate land use direction.

\section{RESEARCH METHOD}

The research was conducted at sub-watershed Jeneberang as a catchment area of Bili-Bili Dam located between $5^{\circ} 11^{\prime} 8^{\prime \prime}-5^{\circ} 20^{\prime} 41^{\prime \prime}$ southern latitude and 119034'30"-119'56'54" east longitude. Basin's catchment area is located at the upriver of Jeneberang watershed with area of $384.4 \mathrm{~km}^{2}(38,440 \mathrm{Ha})$. Location of study for the research is physically located at watershed system of Jeneberang (Figure 1).

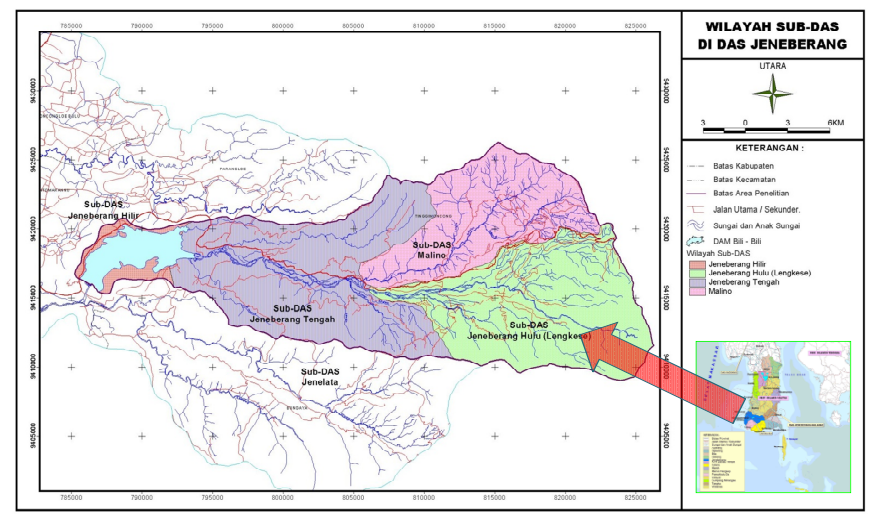

Fig. 1 Map of Research Location

Based on data on average daily rainfall in upriver area of Jeneberang watershed, according to Schmith and Ferguson' climate classification, research location is within the $\mathrm{B}$ climate type with the average number of wet season is nine months, humid seasons is one month and dry season is two months. Rainy season occurs during October to May, and the peak occurs in December and January. Dry season occurs during June to October. There are seven types of soil in Jeneberang sub-watershed area.
Generally, the type of soil in the area is dominated with Haplortoxs (reddish brown Latosol) and Humitropepts (yellowish brown Latosol). The area has various topographical conditions from flat to steep. As a whole, sub-watershed Jeneberang area is dominated by steep topography areas.

USLE is a parametric model to predict erosion in a land area. USLE allows planner to predict average rate of erosion of certain land in a steep slope with certain rainy pattern for every planting and management activities (land conservation activities). In MWAGNPS model, erosion prediction is conducted using USLE method obtained from the relationship among factors causing erosion, which is (Luis F. Leon and Chris George, 2009):

$$
\begin{aligned}
E & =E I \times K \times L S \times f_{s S} \times f_{s h} \times C \times P \\
\text { Where: } & \\
E & =\text { the amount of eroded land (ton/acre) } \\
E I & =\text { rain intensity energy (feet.ton.inch/acre) } \\
K & =\text { soil erodibility (ton.acre/acre.feet.ton.inch) } \\
L S & =\text { slope length factor } \\
f_{s S} & =\text { slope gradient factor } \\
f_{s h} & =\text { slope shape factor } \\
C & =\text { plant factor } \\
P & =\text { soil management factor }
\end{aligned}
$$

Calculation in MWAGNPS is conducted in three steps. First step is to give the initials to all cells set. This step includes estimation for upriver erosion, run-off volume, time when surface run-off concentrated, sediment and run-off current occurred, pollutant from input point source. The second step is calculating run-off volume leaving the cells and sediment product of the main cell. The main cell is one of cells that does not flow to another cell. Sediment of all cells is then divided into five classes of particle size: clay, loam, fine aggregate, coarse aggregate, and sand. The third step is calculation process to determine the level of concentrated flow, arrange current capacity, and calculate current rate of actual sediment occurred. All data is represented in form of georeferanced grid with cell size of $(500 \times 500) \mathrm{m}$. DEM data is obtained from the result of topographic map analysis, land use map and soil type with scale of 1:50.000 (BPDAS Jeneberang). Rainfall data is obtained from Meteorology and Geophysics Agency (BBWS Pompengan-Jeneberang) represented by rain post of Bili-Bili, Jonggoa and Malino dams. $\mathrm{K}, \mathrm{C}$ and $\mathrm{P}$ factors are divided per grid/cell determined based on determined size with number of grid/cell is in accordance with the area of Jeneberang subwatershed.

Uniformity on projection for all maps should be done so that spatial data from all maps can be overlaid and analyzed. The projection used for the research is UTM (Universal Transverse Mercator) with datum WGS 84 and zone 50S. Map projection transformation is conducted using software extensions Projection Utility Wizard-aided ArcView 3.3 and software ArcGIS 9.2. 


\section{A. Topography}

Based on the processing result of scale of 1:50000 topographic map, the upriver area of Jeneberang watershed has varied topography ranging from flat to very steep. As a whole, sub-watershed Jeneberang area is dominated by steep topography with area of $10.080 \mathrm{Ha}$ (26.22\%) and located on 75 - $5000 \mathrm{~m}$ a.s.l of altitude. Table 1 and Table 2 show clearly on the description of the area and the slope gradient spread and elevation map are displayed in Figure 1 and Figure 2.

\section{B. Land Cover}

Result from analysis of land use map of Jeneberang sub-watershed area indicates that most area is dominated by forest with area of $12.250 \mathrm{Ha}(31.87 \%)$ and farm/moor of 9.348 Ha (24.32\%). Table 3 displays area based on land use and Figure 3 displays land cover map based on land use.

\begin{tabular}{ccccc}
\multicolumn{3}{c}{ Table 1. Slope Class at Jeneberang Sub-watershed Area } \\
\hline \multirow{2}{*}{ No } & Slope Gradient & \multirow{2}{*}{ Area Shape } & \multicolumn{2}{c}{ Area } \\
\cline { 4 - 5 } & $(\%)$ & & Ha & $\%$ \\
\hline 1 & $0-8$ & Flat & 6.170 & 16,05 \\
2 & $8-15$ & Sloping & 5.550 & 14,44 \\
3 & $15-25$ & Slightly Steep & 9.620 & 25,03 \\
4 & $25-40$ & Steep & 10.080 & 26,22 \\
5 & $>40$ & Very steep & 7.020 & 18,26 \\
\hline \multicolumn{7}{r}{ Total } & & 38.440 & 100,00 \\
\hline
\end{tabular}

Table 2. Elevation of Jeneberang sub-watershed Area

\begin{tabular}{|c|c|c|c|}
\hline \multirow{2}{*}{ No } & \multirow{2}{*}{$\begin{array}{c}\text { Elevation } \\
(\mathrm{mdpl})\end{array}$} & \multicolumn{2}{|c|}{ Area } \\
\hline & & $\mathrm{Ha}$ & $\%$ \\
\hline 1 & $<250$ & 6.605 & 17,18 \\
\hline 2 & $250-500$ & 7.638 & 19,87 \\
\hline 3 & $500-750$ & 7.406 & 19,27 \\
\hline 4 & $750-1000$ & 5.728 & 14,90 \\
\hline 5 & $1000-1250$ & 4.201 & 10,93 \\
\hline 6 & $1250-1500$ & 2.838 & 7,38 \\
\hline 7 & $1500-1750$ & 1.899 & 4,94 \\
\hline 8 & $1750-2000$ & 1.287 & 3,35 \\
\hline 9 & $2000-2250$ & 526 & 1,37 \\
\hline 10 & $2250-2500$ & 224 & 0,58 \\
\hline \multirow[t]{2}{*}{11} & $>2500$ & 88 & 0,23 \\
\hline & Total & 38.440 & 100.00 \\
\hline
\end{tabular}

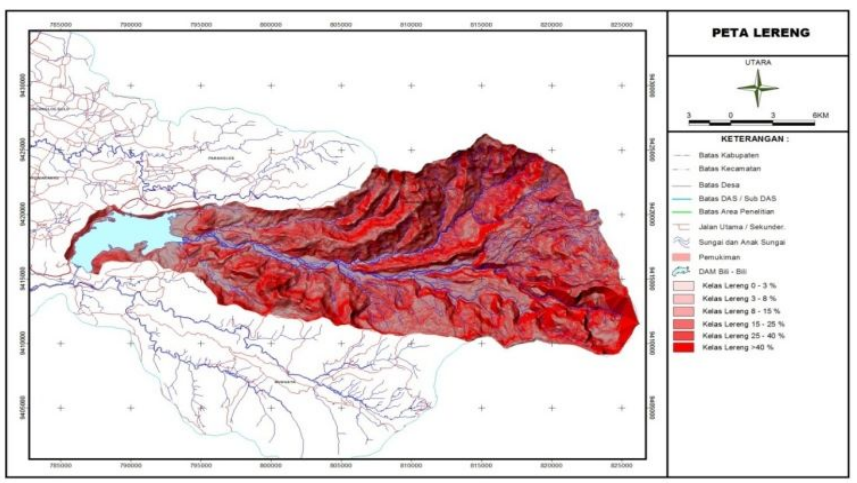

Fig. 1 Map of Slope Class on Jeneberang Sub-watershed Area

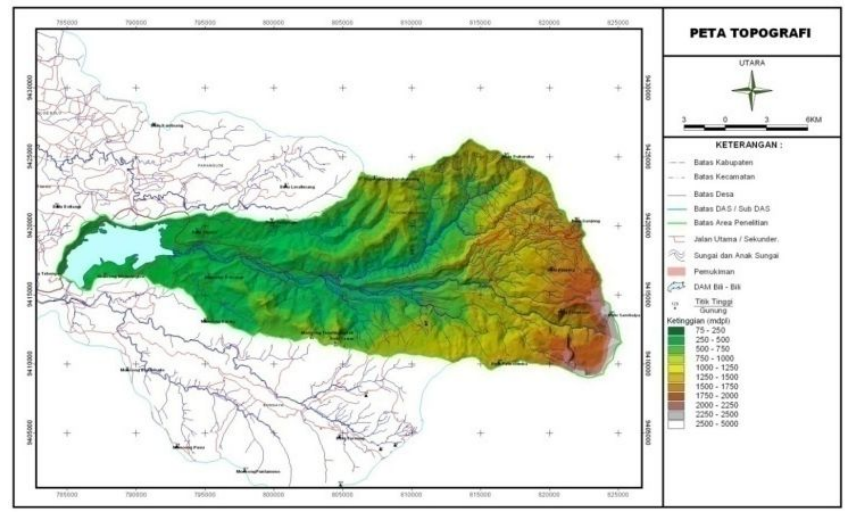

Fig. 2 Map of Elevation of Jeneberang Sub-watershed Area

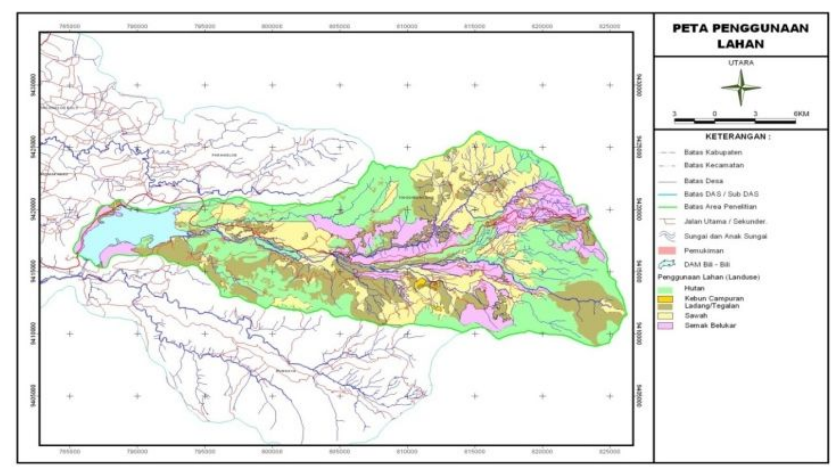

Fig. 3 Land Use Map of Jeneberang Sub-watershed Area

Table 3. Land Use of Jeneberang Sub-watershed Area

\begin{tabular}{clrr}
\hline \multirow{2}{*}{ No } & \multirow{2}{*}{ Land Use } & \multicolumn{2}{c}{ Area } \\
\cline { 3 - 4 } & & \multicolumn{1}{c}{ Ha } & \multicolumn{1}{c}{$\%$} \\
\hline 1 & Forest & 12.250 & 31,87 \\
2 & Farm/Moor & 9.348 & 24,32 \\
3 & Residence & 107 & 0,28 \\
4 & Rice Field & 10.455 & 27,17 \\
5 & Bushes & 6.290 & 16,36 \\
\hline & Total & 38.440 & 100,00 \\
\hline
\end{tabular}

\section{Soil Type}

Based on the result from digital map analysis of soil type on Jeneberang sub-watershed area there are seven types of soil. The type of soil in the area is dominated by Haplortoxs (reddish brown Latosol) of $8.070 \mathrm{Ha} \mathrm{(20.99 \% )}$ and Humtropepts (yellowish brown Latosol) of $7.965 \mathrm{Ha}$ (20.73\%). Clear description on area based on soil type is displayed in Table 4 and soil type map is displayed in Figure 4.

Table 4. Soil Type of Jeneberang Sub-watershed Area

\begin{tabular}{clcr}
\hline \multirow{2}{*}{ No } & \multicolumn{1}{c}{ Soil Type } & \multicolumn{2}{c}{ Area } \\
\cline { 3 - 4 } & & 5.036 & \multicolumn{1}{c}{$\%$} \\
\hline 1 & Dystrandepts (Andosol) & 8.070 & 20,99 \\
2 & Haplortoxs (Latosol) & 7.965 & 20,73 \\
3 & Humitropepts (Latosol) & 3.548 & 9,22 \\
4 & Tropofluvents (Aluvial) & 7.347 & 19,11 \\
5 & Tropohumults (Mediteran) & 3.004 & 7,82 \\
6 & Tropudalfs (Mediteran) & 3.470 & 9,03 \\
7 & Tropudults (Podsolik) & 38.440 & 100.00 \\
\hline
\end{tabular}




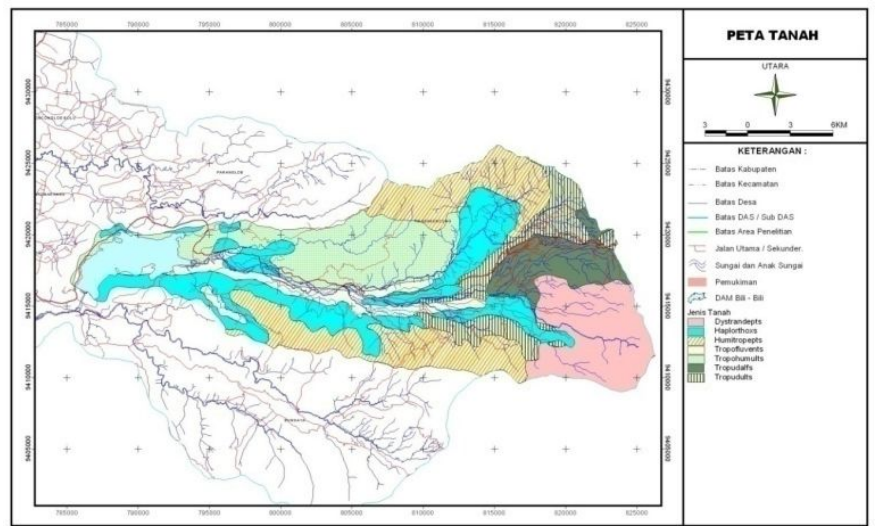

Fig. 4 Soil Type Map of Jeneberang Sub-watershed Area

\section{Rainfall}

Based on seven years average rainfall in the upriver area of Jeneberang watershed it is known that dry season is last from June to October. The average rainfall from three selected station locations is $3,093.3 \mathrm{~mm} /$ year (Table 5). Maximum rainfall is $690 \mathrm{~mm} /$ month and monthly average is $257.78 \mathrm{~mm} /$ month. In watershed Bili-Bili dam, rainfall data was collected from three rainfall stations, Bili-bili dam, Jonggoa and Malino (JICA, 2005).

Table 5. Monthly rainfall at Watershed Bili-Bili Dam (2001-2007)

\begin{tabular}{clrrrrrr}
\hline No. & Location of & \multicolumn{5}{c}{ Monthly Average of Rainfall (mm) } \\
\cline { 3 - 8 } Sta. & Stasiun & Jan & Feb & Mar & Apr & May & June \\
\hline 1 & Bili-Bili Dam & 539 & 491 & 386 & 181 & 97 & 61 \\
2 & Jonggoa & 712 & 533 & 452 & 212 & 64 & 84 \\
3 & Malino & 645 & 624 & 479 & 267 & 126 & 125 \\
& Average & 632,0 & 549,3 & 439,0 & 220,0 & 95,7 & 90,0 \\
\hline
\end{tabular}

\section{E. Analysis on Land Erosion Level}

Land erosion occurs in the area of Jeneberang subwatershed was analyzed using AGNPS program (Young, R.A et al. 1994) with Map Window as an interface (MWAGNPS). Erosion analysis using MWAGNPS was conducted based on topographic digital map, soil type and land cover (Luis F. Leon and Chris George, 2009). Elevation maps from TIN will produce current map as displayed in Figure 5 converted to grid shape with the help of DEM data formed.

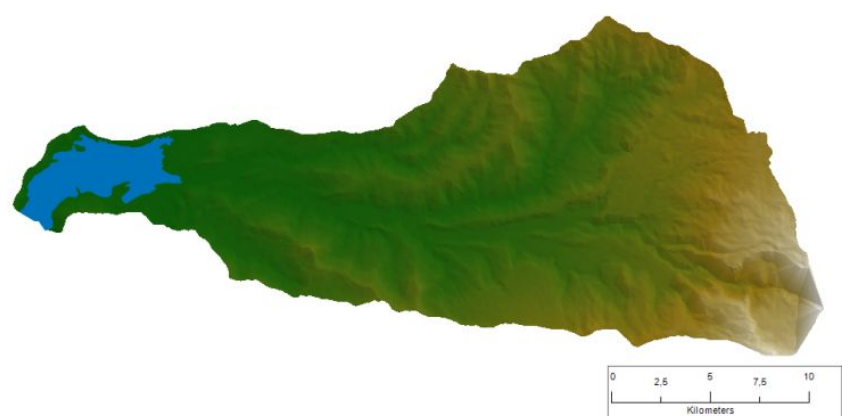

Fig. 5 Elevation DEM Map of sub-watershed Jeneberang

Furthermore, the direction of river flow is obtained based on topographic condition as the accumulation place of the flow from a place with higher elevation to the lower one. Current direction of AGNPS can be seen in Figure 6. Next, imagery map of Jeneberang watershed with scale of 1:50.000 is overlaid with DEM map as the grid basic with resolution of $500 \times 500 \mathrm{~m}$. An area of 25 ha per grid resulted in 1478 grid.

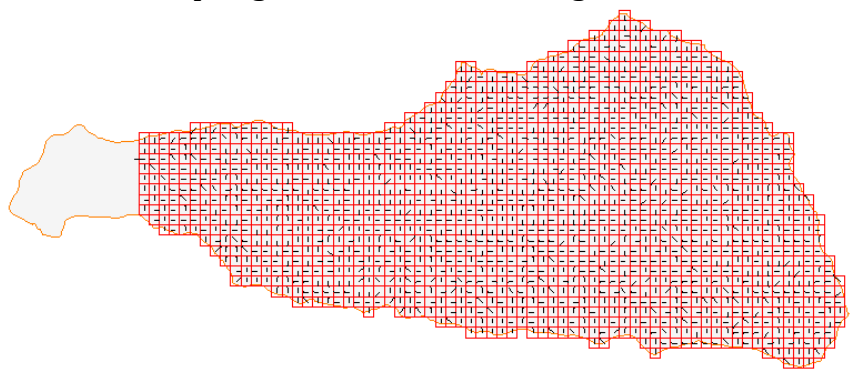

Fig. 6 Current Direction Map of Jeneberang Sub-waterdhed based on Formed Grid

Based on the output result of a model with input value of the biggest average daily rainfall for five years of 31.66 $\mathrm{mm}$ and 30 minutes rain intensity energy $\left(\mathrm{EI}_{30}\right)$ of 25.89 , it is obtained that erosion rate in outlet is 44.81 ton/ha, sedimentation rate is 2.22 ton/ha and total sediment is 203283.0 ton. These results can be seen in Table 6 .

Table 6. The Output of Model Sediment in an outlet of Jeneberang SubWatershed

\begin{tabular}{|c|c|c|c|c|c|}
\hline \multicolumn{6}{|c|}{ Sediment Analysis } \\
\hline \multirow{2}{*}{$\begin{array}{l}\text { Type of } \\
\text { Particle }\end{array}$} & \multicolumn{2}{|c|}{$\begin{array}{c}\text { Erosion per unit of } \\
\text { area }\end{array}$} & \multirow{2}{*}{$\begin{array}{l}\text { NPS } \\
(\%)\end{array}$} & \multirow{2}{*}{$\begin{array}{l}\text { Sediment } \\
\text { per unit } \\
\text { of area } \\
\text { (ton/ha) }\end{array}$} & \multirow{2}{*}{$\begin{array}{c}\text { Total } \\
\text { Sediment } \\
\text { (ton) }\end{array}$} \\
\hline & $\begin{array}{c}\text { Land } \\
\text { (ton/ha) }\end{array}$ & $\begin{array}{l}\text { Channel } \\
\text { (ton/ha) }\end{array}$ & & & \\
\hline Clay & 2,87 & 0 & 75 & 2,15 & 196988,00 \\
\hline Dust & 3,22 & 0 & 2 & 0,06 & 5101,98 \\
\hline Fine Aggregate & 22,79 & 0 & 0 & 0 & 1110,50 \\
\hline Coarse Agg. & 12,90 & 0 & 0 & 0 & 63,69 \\
\hline Sand & 3,04 & 0 & 0 & 0 & 18,82 \\
\hline Total & 44,81 & 0 & 5 & 2,22 & 203283,00 \\
\hline
\end{tabular}

The value of sediment delivery ratio (SDR) is approaching $100 \%$ means that all soil eroded is entering the river (Arsyad, S. 2006). NPS in Jeneberang subwatershed is $5 \%$. This value indicates that only $5 \%$ of total erosion occurs in Jeneberang sub-watershed is entering the channel (river) and become sediment. The remaining 95\% settle in other places before reaching the river channel. Type of particle having the highest NPS ratio value is clay particle of $75 \%$; whereas, fine aggregate is mostly eroded with the value of 22.79 ton/ha.

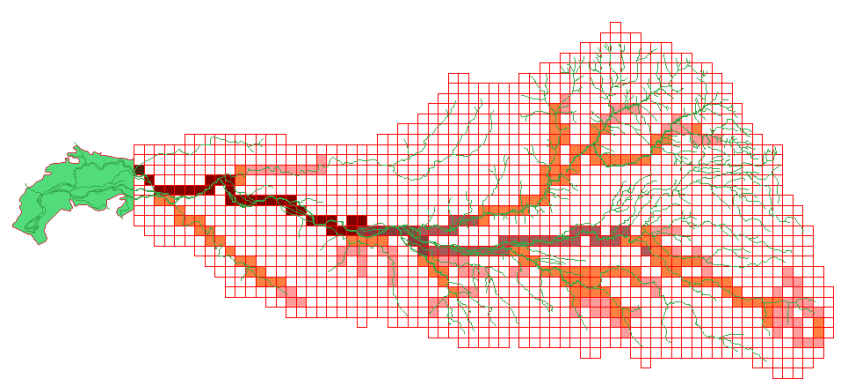

Fig. 7 Total Sediment Distribution Map of Jeneberang Sub-watershed 
Further, the distribution of total sedimentation rate space caused by biggest rain incidence in spatial form is displayed in Figure 7. Based on the figure, it can be seen that total sediment distribution of sub-watershed Jeneberang for every cell is $0-203283.48$ ton. Total sediment is bigger in the grid with river flows. High sedimentation rate causes an increase in the amount of sediment precipitate along the river. It is getting to be more and more sediment in outlet. This is one of causes for the increase of sediment in Bili-Bili dam and might cause the dam will not work properly.

In addition, recapitulation of erosion rate for various land cover based on information from every grid/cell is presented in Table 7 . The biggest surface erosion rate is in the cell with land cover of farm/moor of 29,552.14 ton/ha and bushes of 24,545.38 ton/ha. Forest, rice field and residency have relatively small erosion rate.

The distribution of surface erosion rate caused by the biggest average rain event in spatial form is displayed in Figure 8. The picture shows that the distribution of surface erosion rate on Jeneberang sub-watershed in every cell is around 0-2500 ton/ha. Dominant event for the biggest erosion is on upriver area with steep to very steep slope. Area with land cover of forest is able to restrain surface runoff rate; therefore, runoff rate and volume are decreasing (Asdak, C. 2010).

Table 7. Recapitulation of Erosion Rate and Total Sediment for Various Land Cover

\begin{tabular}{|c|c|c|c|}
\hline Land Cover & Area (ha) & $\begin{array}{c}\text { Erosion Rate } \\
\text { (ton/ha) }\end{array}$ & $\begin{array}{l}\text { Total Sediment } \\
\text { (ton) }\end{array}$ \\
\hline Forest & 12.250 & $8.138,30$ & $674.773,07$ \\
\hline Farm/Moor & 9.348 & $29.552,14$ & $4.562 .625,84$ \\
\hline Residency & 107 & 471,41 & $32.224,13$ \\
\hline Rice Field & 10.455 & 131,02 & $1.201,08$ \\
\hline Bushes & 6.290 & $24.545,38$ & $2.263 .870,34$ \\
\hline
\end{tabular}

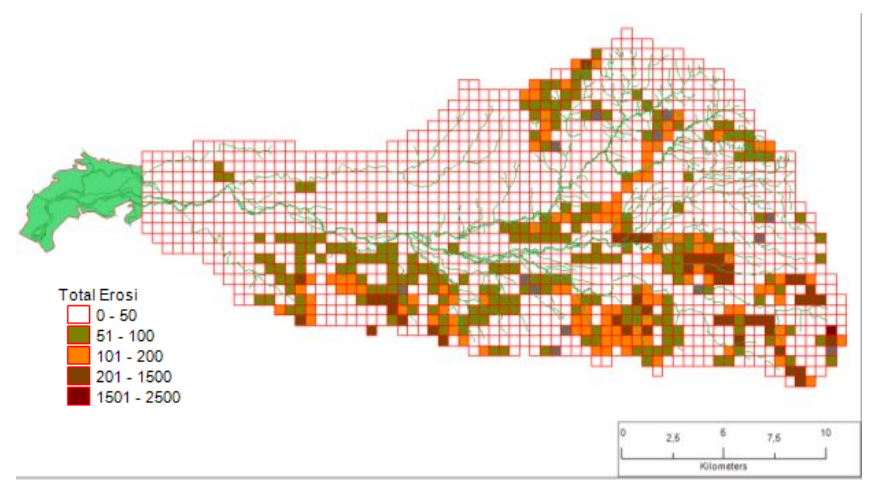

Fig. 8 Map of the Distribution of Surface Erosion Rate on Jeneberang Subwatershed

By knowing the existing erosion level for various land cover completed with location map, more effective land use can be done to decrease erosion flow rate. It can be done by maintaining the existing land use, except for farm/moor and bushes, which are need to be converted into other land use similar to production natural forest. Therefore, directions for land use on sub-watershed Jeneberang in general are applying soil and water conservation techniques, returning forest area as a protected forest and applying sedimentation control system with sabo dam.

\section{CONCLUSIONS}

1. The output of MWAGNPS model with input of the biggest average daily rainfall for 5 years of $31.66 \mathrm{~mm}$ and 30 minutes rain intensity energy $\left(\mathrm{EI}_{30}\right)$ of 25.89 resulted in land erosion rate in the outlet of 44.81 ton/ha, sedimentation rate of 2.22 ton/ha and total sediment of 203283.0 ton.

2. Based on information from every grid/cell for variuos land cover, it is found that the biggest surface runoff rate is in cell with land cover of farm/moor of $29,552.14$ ton/ha and bushes of $24,545.38$ ton/ha. Whereas, forest, rice field and residency have relatively small erosion rate.

3. Directions for land management on sub-watershed Jeneberang are applying soil and water conservation techniques and returning forest area as protected forest.

\section{References}

[1] Abdullah, M.N., Ahmad M. dan Syamsul Arifin I. (2003). Land-use Based GIS-Modelling for Sedimentation Reduction at Bili-Bili Dam, Indonesia. Journal IAHS. 279:180-187.

[2] Arsyad, S. (2006). Soil and water Conservation (Konservasi Tanah dan Air). Second Edition. IPB Press. Bogor.

[3] Asdak, C. (2010). Hydrology and Watershed Management (Hidrologi dan Pengelolaan Daerah Aliran Sungai). Gadjah Mada University Press. Third Edition. Yogyakarta.

[4] Boix-Fayos, C., Vente, J., Martinez, M., Barbera, G., and Castillo,V. 2008. The Impact of Land Use Change and Check-Dams on Catchment Sediment Yield. Journal of Hydrological Processes. 22(25): 4922-4935.

[5] JICA. (2005). The Study on Capacity Development for Jeneberang River Basin Management in the Republic of Indonesia. Final Report. Volume 1. Japan International Cooperation Agency.

[6] Luis F.Leon and George, C. [2009]. Map Window Interface for AGNPS (MWAGNPS) Release 1.

[7] Young, R.A, and Onstad. [1994]. Agricultural NonPoint Source Pollution Model, Version 4.03. AGNPS user's Guide. North Central Soil Conservation Research Laboratory Morris. MN. 